\title{
Do Statisticians Support a Better Work- Life Balance? A Pilot Study*
}

\author{
Submitted 19/10/21, 1st revision 13/11/21, 2nd revision 19/01/22, accepted 20/02/22
}

\author{
Alexandra Livada ${ }^{1}$, Dimitra Cheloni ${ }^{2}$
}

\begin{abstract}
:
Purpose: In this paper, we apply and extend Valcour's model regarding the work-life balance of statisticians in Greece. This is a pilot study which examines the overall level of satisfaction regarding the meeting of work and family or personal role demand.

Design/Methodology/Approach: We use survey data, collected from a questionnaire addressed to graduates from the Statistics Department of the Athens University of Economics and Business. Hierarchical Regression model and the Generalized Multiple Linear Regression model (GLM) are used to estimate an extended version of Valcour's model(2007).

Findings: Results show a negative relationship between satisfaction (from balancing work and personal or family life) and total working hours, commute time, neuroticism and number of children. At the same time, the use of the GLM model strengthens Valcour's model by receiving additional information about the magnitude of the impact of changes in demographic and social factors on satisfaction.

Practical Implications: The results regarding the work -life balance has managerial implcations. An organization which takes into account these findings provides a good work environment and facilities increasing the motivation of the employees.
\end{abstract}

Keywords: Work life-balance, job satisfaction, employee retention, applied statistics, GLM.

JEL codes: M12, I131.

Paper type: Research article.

Acknowledgements: We would like to thank Professor S. Foundas and J. Halikias for their constructive comments and suggestions.

\footnotetext{
${ }^{\text {I} A s s o c i a t e ~ P r o f e s s o r ~ a t ~ A t h e n s ~ U n i v e r s i t y ~ o f ~ E c o n o m i c s ~ a n d ~ B u s i n e s s, ~ l i v a d a @ a u e b . g r ~}$

${ }^{2} \mathrm{MSc}$., Graduate at Athens University of Economics and Business

*This article has been presented at ICABE 2021 at WPUNJ www.icabe.gr
} 


\section{Introduction}

Balancing work and personal or family life is an issue that has been the subject of the research community for many years. Studies show that as the conflict between work and personal life decreases the more the well-being of the individual and his/her productivity increases, making the study of this relationship very crucial for both the workers themselves and their employers. Since the previous century there are theories which attempt to interpret the relationship between work and family/personal life. Valcour's (2007) theoretical model is among the mostly discussed focusing on the resource drain approach and resource-and- demands models introducing at the same time the concept of satisfaction with that of worklife/family balance.

Being statisticians ourselves we come across many problems and advantages our graduates face regarding their work - life balance. Due to this we decided to apply and extend the Valcour's model in order to examine empirically the validity of the model hypotheses for the case of statisticians. We consider this study as a pilot one. The quantitative methodologies we apply, the Hierarchical Regression model and the Generalized Multiple Linear Regression model (GLM), is both based on data collected from a questionnaire addressed to graduates from the Statistics Department of the Athens University of Economics and Business.

The findings of the study verify the hypotheses examined by the Valcour (2007) and in particular the negative relationship between satisfaction (from balancing work and personal or family life) and total working hours, commute time, neuroticism and number of children. At the same time, the use of the GLM model strengthens Valcour's model by receiving additional information about the magnitude of the impact on satisfaction in changes in demographic and social factors.

\section{Literature Review}

The exploration of historical developments in theories and measures of work-family relationships reveals at least seven major theories. These are the theories of segmentation, structural functionalism, compensation, supplemental and reactive compensation, spillover, role enhancement and work enrichment model. There are also, three main views; those of conflict, compensation and balance view (Lavassani and Movahedi, 2014) (Figure 1).

Two basic concepts lie behind the theories of conflict. Firstly, the approval of the separation or segmentation between work and family life and secondly they entire focus on the negative effects of work on family relationships and vise-versa (Lavassani and Movahedi, 2014). Two theories that go back to the industrial revolution are structural functionalism and segmentation theory. Structural functionalism claims that work and family are two separate spheres at the workplace 
takes place the productive life and at home the affective one. On the other hand, according to the segmentation theory, the role pressure from the one sphere (work or family), does not affect the other (Michela and Hargis, 2008).

By the late 1960s, new theories such as the theory of role conflict, interrole conflict and work-family conflict developed in order to describe work and family relationships. Based on the work of Kahn et al. (1964) and Greenhaus and Beutell (1985) defined work-family conflict as "a form of interrole conflict in which the role pressures from the work and family domains are mutually incompatible in some respect" and recognized three main forms of work-family conflict, the time-based conflict created by insufficient time to meet the demands of both roles, the strainbased conflict produced by the fact that one role makes it difficult to meet the responsibilities and requirements of another and the behavior-based conflict generated by the fact that behaviors appropriate in one environment may be incompatible with behaviors needed in another.

As opposed to segmentation, several studies in late 1970s started questioning the idea that work and home are independent and examining how they could affect each other. The roots of the compensation theory can be traced on the research of Piotrkowski (1979) and her findings on a qualitative study of working class families that men "look their homes as havens, look to their families as sources of satisfaction lacking in the occupational sphere" (Piotrkowski, 1979). With her research on the linking processes of work and family relationship Lambert, 1990, advanced further Piotrkowski's view by stating that "compensation occurs when workers respond to unsatisfying job or family conditions by becoming more involved in the other sphere, in hopes of securing greater satisfactions there" (Lambert, 1990).

In other words compensation represents the efforts to offset dissatisfaction in one domain by seeking satisfaction in the other (Edwards and Rothbard, 2000). Two main forms of compensation can we recognize in theories of work-family relationships; firstly a reallocation of importance, time or attention from the dissatisfying domain (work or family) to the potentially satisfying one and secondly the dissatisfaction in one domain that is followed by pursuing rewards in another. This later form of compensation may further categorized to supplemental and reactive compensation (Edwards and Rothbard, 2000).

The theories of balance started to develop in the late 1980s and early 1990s. What distinguished these theories is that they recognized both the positive and negative effects of work to family and vice versa, focusing more on the positive effects (Lavassani and Movahedi, 2014). Three are the main theories or models of the balance view, the role enhancement theory, the spillover theory and the work enrichment model.

The role enhancement theory, emphasizes that multiple roles mean at the same time multiple rewards. Such rewards are for example the necessary income, an increased 
self-esteem, the building of social relationships, and success. In this sense, the combination of roles may have more positive (than negative) impact on the wellbeing of individuals.

Figure 1. Historical developments in theories and measures of work-family relationships

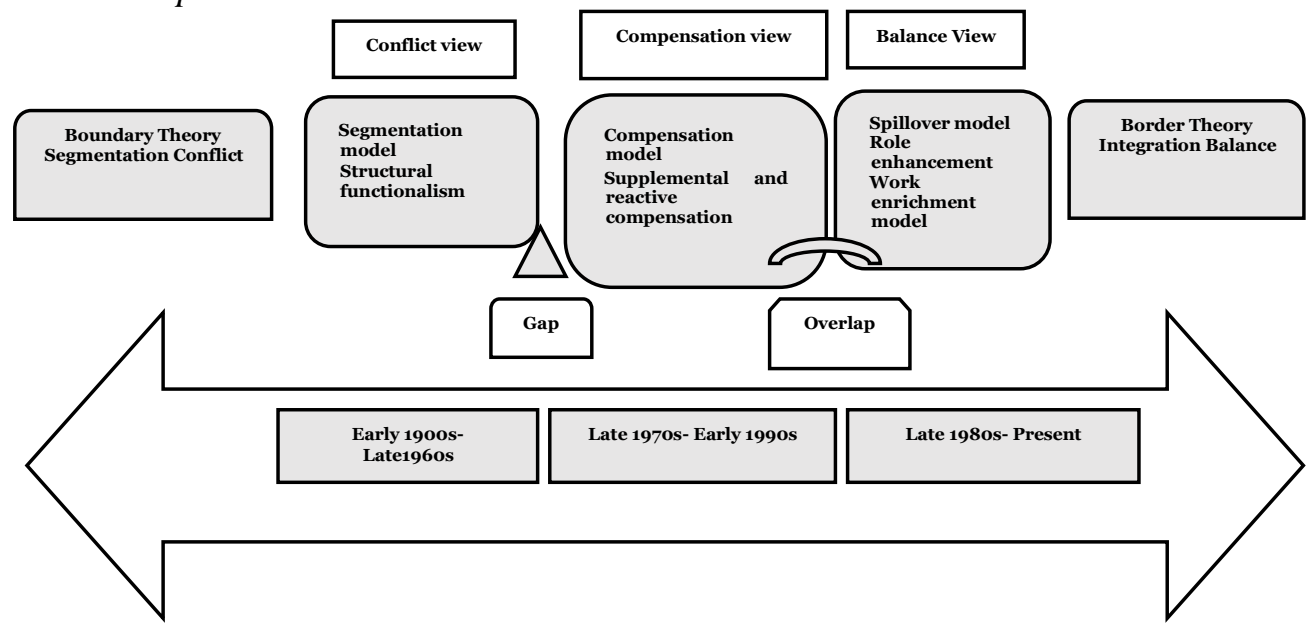

Source: Lavassani, K.M., Movahedi, P. (2014), Developments in theories and Measures of Work-Family, Contemporary Research on Organization Management and Administration.

Nevertheless, when a person reaches his/her energy limits, then the negative symptoms of the fatigue, tension or stress appears. The emphasis, however, is given to positive effects, such as resource enhancement, work family success or balance, positive spillover, and facilitation (Frone, 2003; Lavassani and Movahedi, 2014).

On the other hand, the spillover effects theory claims that the experience of an employee in one area of his life (work or family) is able to affect his experience in the other. Spillover effects can be either positive or negative and the impact occurs when events in one area affect in some way the other. For example, according to this theory, employees transfer emotions, values or attitudes and skills from the professional sector to their personal or family life and vice versa. The effects of work on the family can be both positive and negative. The opposite may also be true (Lavassani and Movahedi, 2014).

The theory of work enrichment is a relatively recent model that explains the relationship between work and family life and has developed by Greenhaus and Powell (2006) gaining increased attention between several researchers. According to this model, experience in one area of life (work or family) will enhance the quality of life in the other area. This model focus mainly on interpreting the positive effects between work and family (rather than the negative ones). The model is based on the idea that both work and family provide individuals with resources, such as increased 
self-esteem, income, and other benefits that help individuals cope better with their different roles or areas (Carlson et al., 2006).

Greenhaus and Powell (2006) suggested that enrichment occurs when the resources acquired in role A, enhance the individual's performance in role B. In other words, enrichment occurs when resources (such as psychological, physical, social and material) acquired from one role either improve directly the performance in the other role (instrumental path) or indirectly (affective path). Some examples of instrumental paths are the acquisition of conflict resolution skills at workplace that can be useful to the family domain in order someone to overcome and resolve more effectively disagreements with his/her partner, children and other family members. At the same time, the patience with which parents treat their children helps them to build better relationships in their work environment (Carlson et al., 2006).

Wayne, 2009, tried to explain the differences between the two measures, that of enrichment and positive spillover. She argued that the positive spillover occurs when an individual transfers the benefit he or she derives from one sector to another. For example, the multiple skills an individual acquires at work can be transferred and applied to the family/ home sector. On the other hand, in order for enrichment to take place, Wayne (2009) argues that the transfer of skills and knowledge acquired, for example at work, must be successfully applied in the home or family sector. Thus, according to Wayne, the two theoretical constructions, although overlapping, are simultaneously distinct (Masuda et al., 2011).

The study of Masuda et al. (2011) proved that the two theoretical constructions are indeed distinct and supported the conclusions of Wayne (2009). In other words, in order for enrichment to take place, the positive effects must first take place. In the context of the above theories, researchers have employed a number of models in their attempt to interpret the relationship between work and family life. Two of the most cited models are that of Grzywach and Mark (2000), and Kinunnen et al. (2006).

The latest theories of work and family relationships that are widely discussed focus mainly on the positive and negative effects that one domain of life (e.g., work) can have on the other (personal or family life) and vice versa as well as on measures such as the role enhancement, the spillover effects, the work enrichment and facilitation. Far from explicitly compute the ideal levels of each component in order a person to feel satisfied, these models may explaining the factors that positively or negatively affect the balance between work and family but fail to define a unique measure for it.

Valcour (2007) examines a set of hypotheses which are based firstly to the resource drain approach (Edwards and Rothbard, 2000) and secondly to the resources -anddemands models (Voydanoff, 2005a). 
Both theories have their roots on the negative relation between family and work domain resulting due to the limited resources, a person has, such as time, effort or attention and money. In other words, given that someone's resources are limited any personal resource consumption on one domain reduces the amount of resources available for meeting the demands of the other domain (Frone et al., 1997; Bakker et al., 2009. More specifically "the use of finite resources (time, energy, or attention) in one life domain (e.g., work) reduces the availability of these same resources for use in another life domain (e.g., family)" (Frone, 2003). When the remaining resources are exhausted or become insufficient then appears the possibility for increased levels of stress or burnout (Edwards and Rothbard, 2000; Frone, 2003).

In this study we have chosen to study on the statistician's work-life balance applying Valcour's model. This is a pilot study wishes to examine the advantages and disadvantages that graduates Statisticians face regarding their work - life balance.

By adopting Valcour's model (2007), the aim of this research is to shed light on a less common construct which aims to measure the overall level of satisfaction with meeting work and family or personal role demands. In Section 3, we discuss the resource drain model approach and analyze the dependent and independent variables of the model. In Section 4 we present the sample and employees' profile and the results of the model. Finally, concluding remarks are presented in Section 5.

\section{Research Methodology}

In order to examine the factors that affect the statistician's work-life balance we apply Valcour's (2007) model with particularly emphasis on additional demographic and social factors. Based on Valcour's model (2007), we examine the following hypotheses:

"Hypothesis 1a: work hours will be negatively related to satisfaction with work family balance"

"Hypothesis 1b: work hours will be positively related to satisfaction with work family balance"

"Hypothesis 2a: job complexity will be positively relate to satisfaction with workfamily balance"

"Hypothesis 2b: job complexity will moderate the relationship between work hours and satisfaction with work -family balance such that longer work hours will have a less negative effect on the work -family balance satisfaction of people with more complex jobs than on the work-family balance satisfaction of people with less complex jobs"

"Hypotheses 3a: Control over work time will be positively related to satisfaction with work-family balance"

"Hypothesis 3b: Control over work time will moderate the relationship between work hours and satisfaction with work - family balance such that longer work hours will have a more negative effect on the work -family balance 
satisfaction of people in jobs with low control over work time than on the work -family balance satisfaction of people in jobs with high control over work time"

"Hypothesis 4: Gender will moderate the relationship between work hours and satisfaction with work- family balance such that longer hours of work will have a more negative effect on women's satisfaction with work - family balance than on men's"

Thus, we focus on the model below:

$$
\begin{gathered}
\text { SWLB = gender }(i)+\text { number of children }(j)+\text { neuroticism }+ \text { commute time }+ \text { ideal hours }+ \\
\text { working hours }+ \text { job complexity }+ \text { job complexity } * \text { hours }+ \text { job control }+ \\
\text { job control } * \text { hours }+ \text { hours } * \text { gender }
\end{gathered}
$$

where the first five independent variables are used as control variables or the base model, and $i$ and $j$ are the levels of the control variables, (e.g., $i=1$, for male, 2 for female).

The dependent variable of the model is the satisfaction with work-family balance (SWLB), which is defined as the "...overall level of contentment resulting from an assessment of how successfully one is handling the sum of demands emanating from work and family roles, rather than an appraisal of how work-domain factors affect the family role and vice versa" (Valcour, 2007). For Valcour (2007) the satisfaction with work-family balance has the advantage of being a holistic unitary approach which measures a unique utility thus offering a testable construct between antecedents and outcomes of interest.

For the overall assessment of satisfaction with work-family balance a five point Likert scale was used (1, very dissatisfied to 5, very satisfied) to allow the respondents to express how much they agree or disagree with the following five items from Valcour, (2007):

a) "How satisfied or dissatisfied are you with the way you divide your time between work and personal or family life". This question emphasizes the time factor.

b) "How satisfied or dissatisfied are you with the way you divide your attention between work and personal or family life". This question emphasizes the attention factor.

c) "How satisfied or dissatisfied are you from how well your work life and your personal or family life fit together". This question assess the degree of success at meeting both demands.

d) "How satisfied or dissatisfied are you with your ability to balance the needs of your job with those of your personal or family life". This question assesses the degree of success at meeting both demands. 
e) "How satisfied or dissatisfied are you with the opportunity you have to perform your job well and yet be able (have enough energy) to perform home - related duties adequately".

The independent variables of the model are work hours, job complexity, control over work time, and demographic or social factors.

Work Hours: Very few studies have directly examined the effect of working hours on work-life balance. This study, following Valcour (2007), and the resource drain theory (Edwards and Rothbard, 2000; Goode, 1960; Greenhaus and Beutell, 1985; Lambert 1990), suggests an inverse relationship between working hours and workfamily balance. This argument is based on the logic that work and personal life or family are interconnected because of the limited resources available to individuals.

Perhaps the most important of these resources is time. Since time is a finite resource that cannot be extended, while at the same time the individual must perform multiple roles, the one hour is devoted from the individual in one area of life (e.g., at work) implies one hour less in the other field (e.g., personal life). Also, the energy available to individuals is not inexhaustible and tends to decrease due to the many working hours. However, other theories, as the theory of enrichment suggests the positive impact that long working hours could have on work-life balance (e.g., long working hours often result in higher wages or earnings that can be used to get a cleaning service or eating meals at a restaurant, thus helping someone to meet the obligation of the house more easily).

For the overall assessment of work hours (and ideal work hours) to the work-family balance we used the following questions:

a) "How many hours do you work in a typical week (excluding overtime)?" (Valcour, 2007);

b) "Do you usually work overtime (more than your normal work hours)?";

c) "How many hours of overtime do you work in a typical week?";

d) "How many hours per week would you ideally like to work?".

Job Complexity: Job complexity has identified as the keystone of the entire job structure (Valcour, 2007). More complex jobs usually require better and higher skills and abilities, are challenging and may give greater autonomy. These characteristics help individuals to develop skills and mental resources that allow them to cope better with the demands of work and family (Voydanoff, 2004; McCauley, Ruderman, Ohlott, and Morrrow, 1994). Such skills are for example planning, organizing, engaging in many activities at the same time, negotiating, communicating and motivating others (Ruderman, 2002). This study therefore suggests a positive relationship between job complexity and work-life or family balance. 
For the measurement of job complexity the questions of Job Characteristics Inventory were used and a five point Likert scale (1, none or almost none to 5, maximum) to allow the respondents to express to what extent:

a) "This job requires me to do many things at work using a variety of skills and talents";

b) "This job involves doing whole and identifiable piece of work with an obvious beginning and end";

c) "The result of my job is likely to significantly affect the lives or well-being of other people";

d) "This job permits me to decide on my own on how to go about doing the work";

e) "The job gives me considerable opportunity for independence and freedom in how I do the work";

f) "Besides feedback from my co-workers or supervisors, this job actually provides clues on how well I am doing my work".

Control over work time: Control over working hours can increase the satisfaction that a person receives from work-life balance. When someone can choose how much to work and when, that increases his/her ability to meet both work and family responsibilities and reduces the pressure he/she feels. Thus, this study suggests a positive relationship between job control and work-life or family balance. Moreover, the resource drain theory points out the fact that control over work time may moderate the negative effect of long working hours to the work-life or work-family balance.

For the measurement of the control over work time the questions of Valcour (2007) have been used and a five point Likert scale (1, none or almost none to 5 , maximum) to allow the respondents to express to what extent:

a) "I control the working days during the week.";

b) "I control the begin and end of the workday";

c) "I control the number of hours I work each week";

d) "I control when I can take a few hours off";

e) "I control when I take vacations or days off".

Gender: Women continue to devote much longer time on home responsibilities even when work the same hours as men. Moreover it is more possible that they take care of a sick child or an elderly parent. If that is true long working hours will have a more negative effect on women's work-life balance than that of men. This study suggests that long working hours will have a more negative effect on women's work-life balance than that of men. Gender was a dummy variable coded as " 0 " for men and " 1 " for women.

Demographic/social factors: The study examines the impact on satisfaction that can have other demographic factors such as commute time, neuroticism, age, marital 
status, number of children, the status of cohabitation, the annual income, the number of employees, the work status of one's relationship and professional experience in years.

For the variable of commute time we used the open question of "how long does it take you on average to make a one-way trip between home and work" and for neuroticism we asked participants to indicate in a scale 1 to 4 how well each of the characteristics describes them, moody, worrying, nervous and calm.

For the variable of age we asked the respondents to choose one of the following age groups: $15-24,25-34,35-44,45-54,55-64,65+$ and for marital status to select between the following status: single, in a relationship engaged $/ \mathrm{married} / \mathrm{marriage}$ contract/divorced.

For the status of cohabitation we used four categories; I live alone, I live together with my relationship/spouse, I live with my parents, I live with friends or relatives, and for the number of employees we used the question "How many employees does your company have" with three possible answers, work alone (from home/singleperson enterprise), 1 up to 10 employees, over 10 employees.

For the variable of professional experience participants could choose between five categories, a year or less, 1 - 3 years, 4 - 6 years, 6 - 10 years, 10 or more years, and finally for the work status of one's relationship participants were asked to answer yes or no to the following question "If you are in a relationship or married, does your partner work?".

In order to examine the validity of the hypotheses 1 to 4 we first used the hierarchical regression analysis. Hierarchical regression analysis allows for a better control of the regression process as the independent variables are introduced in stages, based on a theory or logic. With this method the results are produced in stages and the researcher can monitor whether the addition of the last independent variable led to a better fit or significantly increased the value of the coefficient of determination ( $\mathrm{R}$ squared). At every step we examined the significance of $\mathrm{R}$ square change.

At step 1, we added all the demographic (or control) variables we want to examine (the gender, the number of children, neuroticism, commute time and ideal working hours). At step 2 we added the variable of total working hours. We then used this step to test the validity of hypotheses $1 \mathrm{a}$ and $1 \mathrm{~b}$. At step 3 we added two variables, job complexity and its interaction with total working hours. We then used this step to test the validity of hypotheses $2 \mathrm{a}$ and $2 \mathrm{~b}$. At step 4 , we added the last two variables, job control and its interaction with total working hours. We used this step to test the validity of hypotheses $3 \mathrm{a}$ and $3 \mathrm{~b}$. Finally, at step 5, we added the interaction between gender and total working hours. We used this step to test the validity of hypotheses 4. Moreover, in order to reduce multicollinearity, we applied deviations from the 
mean (in steps 3, 4 and 5) before forming the interaction term ( Aiken and West, 1991).

We continue with another specification, the generalized multiple linear regression model, shown below:

$$
\begin{gathered}
S W L B=\text { gender }(i)+\text { age }(j)+\text { enterprise size }(k)+\text { number of children }(m)+\text { work status } \\
\text { of } \\
\text { one's relationship }(n)+\text { commute time }+ \text { neuroticism }+ \text { working hours }+ \text { job } \\
\text { control }+ \text { job complexity } * \text { hours }
\end{gathered}
$$

where gender, age, enterprise size, number of children, work status of one's relationship are the factors of the model, commute time, neuroticism, working hours, job control, job complexity are the continuous variable or covariates, and $\mathrm{i}, \mathrm{j}, \mathrm{k}, \mathrm{l}, \mathrm{m}$ are the levels of the factors (e.g., $i=1$, for male, 2 for female).

We have chosen the GLM model due to: a) the number of categorical variables. If we had one or two binary categorical variables, this would not offer a major advantage. But in our case, where we have many categorical variables that are multicategory, the GLM model offers us a great advantage, both in terms of time savings and also in achieving an overall p-value for the variable as a whole. b) In the GLM model we can easily add interactive factors. On the other hand in the simple multiple linear regression analysis, we must create each interaction as a separate variable.

Once again, this can be very tedious, especially if these interactions contain categorical variables (as in our case). Applying the method of backward reduction, we keep all variables significant at p-value $<10 \%$. We then applied the generalized multiple linear regression model (GLM) to the chosen variables.

Finally, before applying the two methods (hierarchical regression analysis and GLM) we checked for multicollinearity through variance inflation factor (VIF). In each step we examined each of the independent variables as a function of the other independent variables and the value obtained by the VIF factor. The values for all the independent variables were within safe limits (close to 1), indicating that there is no problem of multicollinearity in our data.

\section{Results}

The questionnaire of our survey was distributed randomly to 100 statistician who were in the labour sector. Our sample was taken from the list of postgraduates from the Statistics department of the AUEB. The valid questionnaires were 72.

Regarding the demographic profile of the respondents, most of the participants in the research are females (51\%), compared to males (49\%). The majority of the respondents are between 25-34 years old (56\%), followed by those who are 35-44 
years old (24\%). Regarding the marital status of those who participated in the research, $57 \%$ are married or they live with a partner. On the contrary, 39\% are single and $4 \%$ are divorced/separated. In addition, $81 \%$ of the participants do not have any children, $14 \%$ have two children and $5 \%$ have one child.

Regarding their cohabitation status, $49 \%$ live with their partner and $25 \%$ with their parents, the rest live alone or with friends and other relatives. Most of them (46\%) earn less than $12.000 €$ while $37,5 \%$ earn $12.000-25.000 €$ and only few earn more than $40.000 €$. They work either as private or civil servants $(47,2 \%)$ or as selfemployed $(27,8 \%)$. They work either in enterprises with more than 10 employees $(76,4 \%)$ or in micro enterprises with max 10 employees $(15,3 \%)$ and $8,3 \%$ are selfemployed. Also, most of the employees (72\%) have over 4 years of work experience.

Table 1, presents the Hierarchical Regression Analysis (model 1). Starting from step 1 both step 2 and step 3 improved the fit of the model. The opposite is true for the steps 4 and 5 so we proceed to conclusions based on the $3^{\text {rd }}$ step.

Table 1. Hierarchical Regression Analysis - STEPS 1-5

\begin{tabular}{|c|c|c|c|c|c|c|c|c|}
\hline \multirow[b]{2}{*}{ Model } & \multirow[b]{2}{*}{$\mathrm{R}^{2}$} & \multirow{2}{*}{$\begin{array}{l}\text { Adj. } \\
\mathrm{R}^{2}\end{array}$} & \multirow{2}{*}{$\begin{array}{l}\text { SE of the } \\
\text { estimation }\end{array}$} & \multicolumn{5}{|c|}{ Change Statistics } \\
\hline & & & & $\Delta \mathrm{R}^{2}$ & $\Delta \mathrm{F}$ & df1 & df2 & Sig.F \\
\hline $\begin{array}{l}\text { STEP1. Control } \\
\text { (gender, number of children, } \\
\text { neuroticism, commute time, ideal } \\
\text { work hours) }\end{array}$ &, 181 &, 119 & ,22599 & , 181 & 2,923 & 5 & 66 &, 019 \\
\hline STEP2. Work Hours & ,238 &, 168 & ,21970 & 057 & 4,836 & 1 & 65 &, 031 \\
\hline $\begin{array}{l}\text { STEP3. Job Complexity and } \\
\text { interaction job complexity (work } \\
\text { hours } * \text { Job Complexity) }\end{array}$ & ,291 &, 201 & ,21522 &, 053 & 2,366 & 2 & 63 &, 102 \\
\hline $\begin{array}{l}\text { STEP4. Control over work time } \\
\text { and interaction control over work } \\
\text { time (work hours } * \text { Contro over } \\
\text { work time) }\end{array}$ & ,299 &, 184 & ,21754 & ,008 & ,331 & 2 & 61 & ,719 \\
\hline $\begin{array}{l}\text { STEP5. Interaction with gender } \\
\text { (work hours * Gender) }\end{array}$ & ,310 &, 184 & ,21758 & ,011 & ,981 & 1 & 60 & ,326 \\
\hline
\end{tabular}

Source: Own study.

The main results are presented in Table 2, where we notice that:

a) The variable Total Working Hours is statically significant and our data confirm Hypothesis 1a, according to which, working hours are negatively related to the satisfaction from work-life or work family balance.

b) The data are also consistent with, Hypothesis $2 \mathrm{a}$ of the model according to which, the work complexity is positively related to the satisfaction from work-life balance. In contrast, the data do not support Hypothesis $2 b$ of the model that complexity mitigates the negative effects of long working hours. 
c) However, the data do not confirm Hypotheses $3 a$ and $3 b$ according to which control over working hours is positively associated with satisfaction of balancing work and family and mitigates the negative effect of long working hours.

d) Finally, the data do not confirm Hypothesis 4, according to which longer working hours have a greater negative impact on women than men.

Regarding the demographic factors (or control variables) of our model (Table 1, step 3 ), the variable neuroticism is statistically significant while the variable commute time is only significant at a significance level of $\alpha=10 \%$. Both factors are negatively related to satisfaction from balancing work and personal or family life, e.g., more neurotic people show lower levels of satisfaction from balancing work and personal or family life. Similarly, the longer one takes to move from home to work, the less satisfied he/she is with the balance between personal and professional life. On the other hand, our data do not confirm the statistical significance of the other demographic factors of the model, e.g., the gender, the number of children and ideal working hours.

Table 2. Hierarchical Regression Analysis-Coefficients B

\begin{tabular}{|c|c|c|c|c|c|}
\hline & Model & $\begin{array}{l}\text { Coefficient } \\
\text { s B }\end{array}$ & Std.error & $\mathrm{t}$ & Sig. \\
\hline \multirow[b]{6}{*}{ STEP1. } & (Constant) & 2,091 & 0,139 & 15,023 &, $000 * * *$ \\
\hline & GENDER & 0,083 & 0,055 & 1,503 & 0,138 \\
\hline & NUMBER_OF_CHILDRE & 0,006 & 0,038 & 0,146 & 0,884 \\
\hline & NEUROTICISM & $-0,115$ & 0,043 & $-2,662$ &, $010 * *$ \\
\hline & COMMUTE_TIME & $-0,003$ & 0,002 & $-2,245$ &, $028^{*}$ \\
\hline & IDEAL_HOURS & 0 & 0,003 & 0,02 & 0,984 \\
\hline \multirow[b]{7}{*}{ STEP 2.} & (Constant) & 2,324 & 0,172 & 13,514 & 0 \\
\hline & GENDER & 0,06 & 0,054 & 1,103 & 0,274 \\
\hline & NUMBER_OF_CHILDRE & 0,02 & 0,038 & 0,535 & 0,594 \\
\hline & NEUROTICISM & $-0,116$ & 0,042 & $-2,78$ &, $007 * *$ \\
\hline & COMMUTE_TIME & $-0,003$ & 0,001 & $-1,824$ &, $073 *$ \\
\hline & IDEAL_HOURS & 0 & 0,003 & 0,192 & 0,849 \\
\hline & TOTAL_WORK_HOURS & $-0,006$ & 0,003 & $-2,199$ &, $031 *$ \\
\hline \multirow[b]{9}{*}{ STEP 3} & (Constant) & 2,024 & 0,228 & 8,873 & 0 \\
\hline & GENDER & 0,069 & 0,054 & 1,265 & 0,21 \\
\hline & NUMBER_OF_CHILDREN & 0,024 & 0,037 & 0,638 & 0,526 \\
\hline & NEUROTICISM & $-0,094$ & 0,042 & $-2,216$ & ,030* \\
\hline & COMMUTE_TIME & $-0,003$ & 0,001 & $-1,783$ & 0,079 \\
\hline & IDEAL_HOURS & 0,001 & 0,002 & 0,251 & 0,803 \\
\hline & TOTAL_WORK_HOURS & $-0,006$ & 0,003 & $-2,226$ &, $030 *$ \\
\hline & JOB_COMPLEXITY & 0,073 & 0,034 & 2,175 &, $033 *$ \\
\hline & COMPLEXITY_HOURS & 0,001 & 0,004 & 0,271 & 0,787 \\
\hline
\end{tabular}

Note: $* p<.05, * * p<.01, * * * p<.001$

Source: Own study.

Regarding the goodness of fit, as we can see in Figure 2 below, the model meets the hypotheses of normality and homoscedasticity of errors and fits well the data. 


\section{Figure 2. Homoscedasticity and normality}
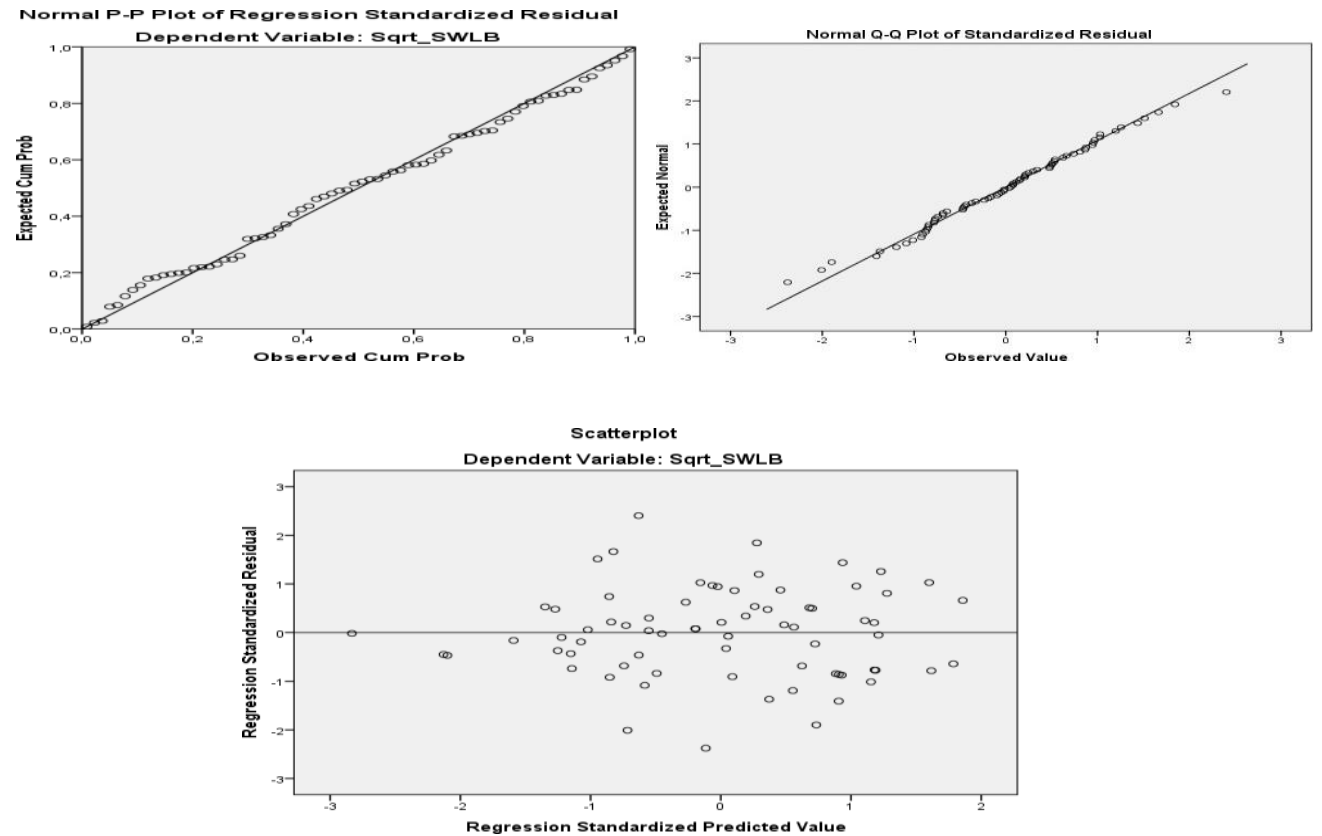

Source: Own study.

We then examined model (2) estimating GLM. Before that we applied the method of backward reduction and we kept all variables significant at $\mathrm{p}$-value $<10 \%$ as we see in Table 3, below.

Table 3. Selection of Variables by the method of backward reduction for the GLM model

\begin{tabular}{|l|c|c|c|c|c|}
\hline Model $^{\mathrm{a}}$ & $\begin{array}{l}\text { Unstandardized } \\
\text { Coefficients }\end{array}$ & & $\begin{array}{l}\text { Stand. } \\
\text { Coefficients }\end{array}$ & $\mathrm{t}$ & Sig. \\
\hline & $\mathrm{B}$ & $\begin{array}{c}\text { Std. } \\
\text { Error }\end{array}$ & Beta & & \\
\hline GENDER & 3,785 &, 679 & & 5,576 &, $000^{* * *}$ \\
\hline AGE_GROUP &, 476 &, 178 &, 274 & 2,670 &, $010^{* * *}$ \\
\hline ENTERPRISE_SIZE &, 393 &, 116 &, 416 & 3,386 &, $001^{* * *}$ \\
\hline TOTAL_WORK_HOURS &, 490 &, 154 &, 352 & 3,186 &, $002^{* * *}$ \\
\hline COMMUTE_TIME &,- 026 &, 009 &,- 310 & $-2,766$ &, $008^{* *}$ \\
\hline RELAT_WORK_STATUS &,- 011 &, 005 &,- 230 & $-2,345$ &, $022^{* *}$ \\
\hline NUMBER_OF_CHILDREN &,- 286 &, 138 &,- 209 & $-2,072$ &, $043^{* *}$ \\
\hline NEUROTICISM &,- 989 &, 422 &,- 811 & $-2,345$ &, $022^{* *}$ \\
\hline JOB_CONTROL &,- 439 &, 132 &,- 331 & $-3,337$ &, $001^{* * *}$ \\
\hline COMPLEXITY_HOURS &, 250 &, 078 &, 334 & 3,208 &, $002^{* * *}$ \\
\hline a. Dependent Variable:SWLB &,- 023 &, 012 &,- 196 & $-1,845$ &, $070^{*}$ \\
\hline
\end{tabular}

Note: $* p<.1, * * p<.05, * * * p<.01$

Source: Own study. 
The main results of our model based on Tables 4 and 5 below are the following:

i. Ceteris paribus (or at a steady level of working hours, commute time, degree of neuroticism, number of company's employees, number of children, etc.) men receive less satisfaction from the balance between work and family life.

ii. Ceteris paribus, older people enjoy greater satisfaction from work-life balance than youngers. Specifically, people belonging to the age group 15-24 years receive up to 2.85 points less satisfaction from work-life balance than people aged $65+$ (the control group). In addition, the ages $25-34$ and $35-44,45-54$ receive $2,1.9$ and 0,926 points less satisfaction from work-life balance, respectively, compared to the control group (people aged 65+).

iii. Ceteris paribus, the self-employed individuals receive less satisfaction from work-life or family balance. That is, self-employed receive up to 1.2 points less satisfaction from work-life or family balance than people who work in companies that employ more than 10 employees (for people who belong to the same sex, have the same marital status, etc.).

iv. Ceteris paribus, people who do not have a partner receive less satisfaction from work-life or family balance than people who have a partner (whether she/he works or not). That is, people who do not have a partner receive up to 0.6 points less satisfaction from work life or family balance than people who have a partner who does not work, and 0.4 points less satisfaction than people who have a partner who works.

v. Ceteris paribus, as the number of children increases, the satisfaction from workfamily balance decreases. That is, non-parents receive up to 0.9 points more satisfaction from work-life or family balance than people with two children. Also, the parents of one child receive more satisfaction from work-life or family balance by 1.4 points compared to the parents of two children (for people who belong to the same sex, work in a company with the same number of employees, etc.).

vi. There is a negative relationship between total working hours and satisfaction from work-family or life balance.

vii. There is a minor but negative correlation between commute time and satisfaction from work-life or family balance. Ceteris paribus, the longer the commute time, the lower the individual's satisfaction from work-life or family balance.

viii. There is a strong negative relationship between neuroticism and satisfaction from work-life or family balance.

ix. There is a strong positive relationship between control over working hours and satisfaction from balancing work and personal or family life. 
x. Ceteris paribus, the complexity of the work mitigates the negative effect of the many working hours.

Table 4. The results of the GLM model

\begin{tabular}{|l|c|c|c|}
\hline \multicolumn{1}{|c|}{ Tests of Model Effects } & $\begin{array}{c}\text { Wald Chi- } \\
\text { Square }\end{array}$ & df & Sig. \\
\hline (Intercept) & 180,136 & 1 &, 000 \\
\hline GENDER & 8,972 & 1 &, 003 \\
\hline AGE_GROUP & 18,498 & 5 &, 002 \\
\hline ENTERPRISE_SIZE & 12,388 & 2 &, 002 \\
\hline RELAT_WORK_STATUS & 7,213 & 2 &, 027 \\
\hline NUMBER_OF_CHILDREN & 11,593 & 2 &, 003 \\
\hline HOURS_CENTERED & 10,465 & 1 &, 001 \\
\hline COMMUTE_TIME & 3,741 & 1 &, 053 \\
\hline NEUROTICISM & 9,740 & 1 &, 002 \\
\hline CONTROL_CENTERED & 10,623 & 1 &, 001 \\
\hline COMPLEXITY_HOURS & 4,165 & 1 &, 041 \\
\hline
\end{tabular}

Note: $* p<.1, * * p<.05, * * * p<.01$

Source: Own study.

Table 5. Parameters' Estimates

\begin{tabular}{|c|c|c|c|c|c|c|}
\hline & \multirow[t]{2}{*}{$\mathrm{B}$} & \multirow[t]{2}{*}{ SE } & \multicolumn{3}{|c|}{ Hypothesis Test } & \multirow[t]{2}{*}{$\operatorname{Exp}(B)$} \\
\hline & & & $\begin{array}{l}\text { Wald Chi- } \\
\text { Square }\end{array}$ & $\mathrm{df}$ & Sig. & \\
\hline (Intercept) & 5,545 & ,7589 & 53,384 & 1 &, 000 & 255,84 \\
\hline [GENDER=0] &,- 560 &, 1869 & 8,972 & 1 & ,003 & ,571 \\
\hline$[$ GENDER=1] & $0^{\mathrm{a}}$ & . & $\dot{v}$ & . &. & 1 \\
\hline [AGE_GROUP=0] & $-2,851$ & ,9187 & 9,631 & 1 & ,002 & ,058 \\
\hline [AGE_GROUP=1] & $-1,988$ &, 7941 & 6,269 & 1 &, 012 &, 137 \\
\hline [AGE_GROUP=2] & $-1,913$ &, 7750 & 6,095 & 1 &, 014 &, 148 \\
\hline [AGE_GROUP=3] &,- 926 &, 7785 & 1,413 & 1 &, 234 & ,396 \\
\hline [AGE_GROUP=4] &,- 621 & ,8989 & ,478 & 1 &, 489 & ,537 \\
\hline [AGE_GROUP=5] & $0^{\mathrm{a}}$ & $\cdot$ & . & . & . & 1 \\
\hline [ENTERPRISE_SIZE=0] & $-1,167$ & ,3387 & 11,869 & 1 & ,001 & ,311 \\
\hline [ENTERPRISE_SIZE=1] &,- 042 & ,2488 &, 028 & 1 & ,866 & ,959 \\
\hline [ENTERPRISE_SIZE=2] & $0^{\mathrm{a}}$ & . & . & . & 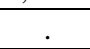 & 1 \\
\hline [RELAT_WORK_STATUS=0] & ,693 & 2974 & 5,433 & 1 &, 020 & 2,000 \\
\hline [RELAT_WORK_STATUS=1] & ,416 & ,1960 & 4,504 & 1 & ,034 & 1,516 \\
\hline [RELAT_WORK_STATUS=2] & $0^{\mathrm{a}}$ & . & . & . & 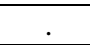 & 1 \\
\hline [NUMBER_OF_CHILDREN=0] & ,924 & ,3238 & 8,147 & 1 & ,004 & 2,520 \\
\hline [NUMBER_OF_CHILDREN=1] & 1,429 & ,4598 & 9,656 & 1 & 002 & 4,174 \\
\hline [NUMBER_OF_CHILDREN=2] & $0^{\mathrm{a}}$ & 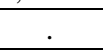 & . & . & . & 1 \\
\hline HOURS_CENTERED &,- 031 & ,0097 & 10,465 & 1 & ,001 & ,969 \\
\hline COMMUTE_TIME &,- 009 & ,0047 & 3,741 & 1 & ,053 & ,991 \\
\hline NEUROTICISM &,- 415 &, 1329 & 9,740 & 1 & 002 & ,661 \\
\hline CONTROL_CENTERED & ,254 & ,0779 & 10,623 & 1 & 001 & 1,289 \\
\hline COMPLEXITY_HOURS &,- 026 &, 0125 & 4,165 & 1 & ,041 & ,975 \\
\hline (Scale) &, $428^{\mathrm{b}}$ & & & & & \\
\hline
\end{tabular}

Note: $* p<.1, * * p<.05, * * * p<.01$

Source: Own study. 
Finally, the adjustment of the model is satisfactory (Figure 3). As we observe in the Normal Q-Q plot diagram the normality hypothesis is not violated (also in the normality test, the p-value $=0.554$, Shaprio-Wilk, so we do not reject the null hypothesis of normality). Moreover, the diagram of Residuals (Pearson residuals) in the predicted values is satisfactory since we do not see any pattern and the residuals seem to be randomly distributed around the line $\varepsilon=0$.

Figure 3. Normality and Homoscedasticity of errors
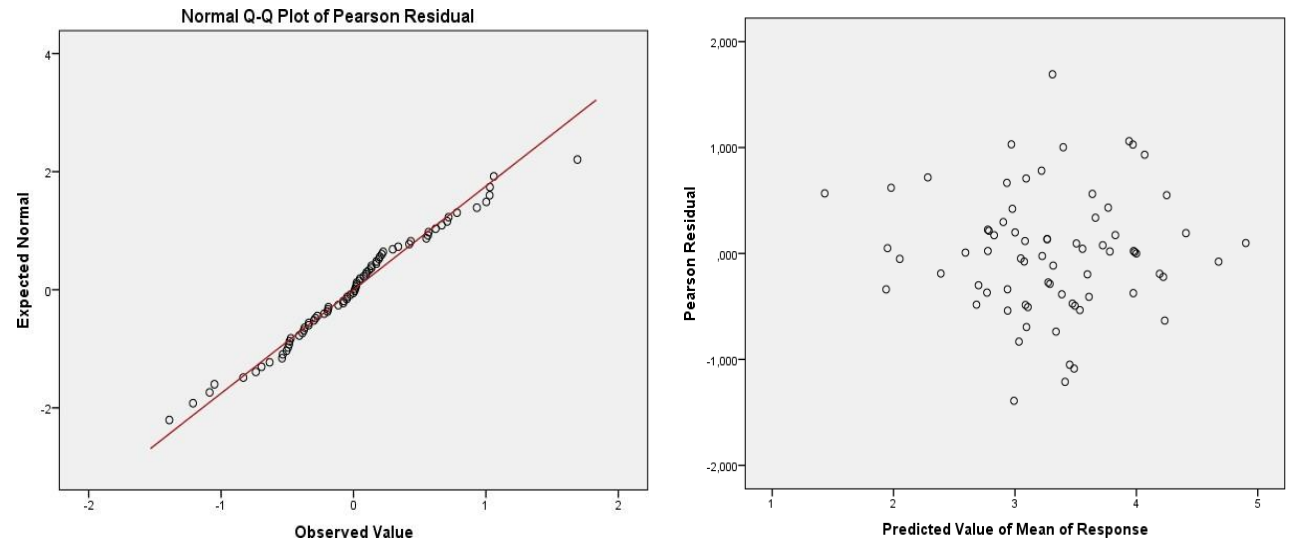

Source: Own study.

\section{Concluding Remarks}

Our study shows that for the statisticians who work in Greece their work-life balance suggests that there is a negative relationship between their satisfaction (from balancing work and personal or family life) and total working hours as well as with commute time, neuroticism and number of children.

However, there is positive relationship with the control over working hours. The GLM model indicated that ceteris paribus, women receive more satisfaction from work-life or family balance than men and that the complexity of the work mitigates the negative effect of the many working hours. So, most of the Valcour's (2007) hypotheses are valid for the case of our survey. Also, the use of the GLM model strengthens Valcour's model by receiving additional information about the magnitude of the impact on satisfaction in changes in demographic and social factors.

Future research could focus on longitudinal data-study where we would be able to present the evolution over time of the work-life/family balance. Lastly but not least, we would like to emphasize the usefulness of these models and their applications for the HR business policies. This affects the welfare of employees and the society as a whole as well as the productivity in businesses and the overall economy. 


\section{References:}

Aiken, L.S., West, S.G. 1991. Multiple regression: Testing and interpreting interactions. Newbury Park, CA. Sage.

Bakker, A.B., Demerouti, E. 2007. The job demands-resources model: state of the art. J. Manag. Psychol., 22, 309-328.

Bakker, A.B., Demerouti, E. 2014. Job demands-resources theory. In: Wellbeing: A Complete Reference Guide, Work and Wellbeing, eds., Chen, P.Y., Cooper, C.L. Chichester, Wiley-Blackwell, 37-64.

Bakker, A.B., Demerouti, E. 2016. Job demands-resources theory: taking stock and looking forward. J. Occup. Health Psychol. DOI:10.1037/ocp0000056.

Bakker, A.B., van Veldhoven, M., Xanthopoulou, D. 2010. Beyond the demand-control model. Pers. Psychol., 9, 3-16.

Carlson, D.S., Kacmar, K.M., Wayne, J.H., Grzywacz, J.G. 2006. Measuring the positive side of the work-family interface: Development and validation of a work-family enrichment scale. Journal of Vocational Behaviour, 68(1), 131-164.

Carvalho, V.S., Chambel, M.J. 2014. Work-to-family enrichment and employees' wellbeing: high performance work system and job characteristics. Soc. Indic. Res., 119, 373-387.

Champoux, J.E. 1978. Perceptions of work and nonwork: A reexamination of the compensatory and spillover models. Sociology of Work and Occupations, 5(4), 402422.

Edwards, J.R., Rothbard, N.P. 2000. Mechanisms linking work and family: Clarifying the relationship between work and family constructs. Academy of Management Review, 25(1), 178-199.

Frone, M.R., Yardley, J.K., Markel, K.S. 1997. Developing and testing an integrative model of the work-family interface. Journal of Vocational Behavior, 50(2), 145-167.

Frone, M.R. 2003. Work Family Balance. In: J.C. Quick, L.E. Tetrick (Eds), Handbook of Occupational Health Psychology, 143-162. Washington, DC., American Psychological Association.

Ghislieri, C., Gatti, P., Molino, M., Cortese, C.G. 2017. Work-family conflict and enrichment in nurses: between job demands, perceived organisational support and work-family backlash. J. Nurs. Management, 25, 65-75.

Goode, W.J. 1960. A theory of role strain. American Sociological Review, 25, 483-496.

Greenhaus, J.H., Beutell, N.J. 1985. Sources of conflict between work and family roles. Academy of Management Review, 10(1), 76-88.

Greenhaus, J.H., Powell, G.N. 2006. When Work and Family are Allies: A Theory of WorkFamily Enrichment. Academy of Management Revies, 31(1), 72-92.

Grzymala-Busse, J.W., Grzymala-Busse, W.J. 2005. Handling Missing Attribute Values. In: Maimon, O., Rokach, L. (eds), Data Mining and Knowledge Discovery Handbook. Springer, Boston, MA.

Grzywacz, J.G. 2000. Work-family spillover and health during midlife: Is managing conflict everything? American Journal of Health Promotion, 14(4), 236-243.

Grzywacz, J.G., Marks, N. 2000a. Family, work, work-family spillover, and problem drinking during midlife. Journal of Marriage and the Family, 62(2), 336-348.

Grzywacz, J.G., Marks, N. 2000b. Reconceptualizing the work-family interface: An ecological perspective on the correlates of positive and negative spillover between work and family. Journal of Occupational Health Psychology, 5(1), 111-126. 
Hackman, J.R., Oldham, G.R. 1976. Motivation through the design of work: test of a theory. Organizational Behavior and Human Performance, 16, 250-279.

Hill, E.J., Hawkins, A.J., Ferris, M., Weitzman, M. 2001. Finding an extra day a week: The positive influence of perceived job flexibility on work and family life balance. Family Relations, 50(1), 49-58.

Kahn, R.L., Wolfe, D.M., Quinn, R.P., Snoek, J.D., Rosenthal, R.A. 1964. Organizational stress: Studies in role conflict and ambiguity. John Wiley.

Kinnunen, U., Feldt, T., Geurts, S., Pulkkinen, L. 2006. Types of work-family interface Wellbeing correlates of negative and positive spillover between work and family. Scandinavian Journal of Psychology, 47(2), 149-162.

Lambert, S.J. 1990. Processes linking work and family: A critical review and research agenda. Human Relations, 43(3), 239-257.

Lavassani, K.M., Movahedi, P. 2014. Developments in theories and Measures of WorkFamily. Contemporary Research on Organization Management and Administration, 2(1), 6-19.

Liu, H., Cheung, F.M. 2015. The role of work-family role integration in a job demandsresources model among Chinese secondary school teachers. Asian J. Soc. Psychology, 18, 288-298.

Masuda, A.D., McNall, L.A., Alen, T.D., Nicklin, J.M. 2011. Examining the constructs of work-to-family enrichment and positive spillover. Journal of Vocational Behavior, 80(1), 197-210.

McCauley, C.D., Ruderman, M.N., Ohlott, P.J., Morrow, J.E. 1994. Assessing the developmental components of managerial jobs. Journal of Applied Psychology, 79(4), 544-560.

Milkie, M.A., Peltola, P. 1999. Playing all the roles: Gender and the work- family balancing act. Journal of Marriage and the Family, 61, 476-490.

Piotrkowski, C. 1979. Work and the family system. New York: The Free Press.

Rothausen, T.J. 1994. Job Satisfaction and the parent worker: The role of flexibility and rewards. Journal of Vocational Behavior, 44, 317-336.

Ruderman, M.N., Ohlott, P.J., Panzer, K., King, S.N. 2002. Benefits of Multiple Roles for Managerial Women, Academy of Management Journal, 45(2), 369-386.

Russo, M., Buonocore, F. 2012. The relationship between work-family enrichment and nurse turnover. J. Manage. Psychology, 27, 216-236.

Schaufeli, W.B., Taris T.W. 2014. A critical review of the job demands- resources model: implications for improving work and health. In: Bridging Occupational, Organizational and Public Health: A Transdisciplinary Approach. Bauer, G., Hämming, O., editors. Dordrecht, Springer, 43-68.

Thomas, L.T., Ganster, D.C. 1995. Impact of family-supportive work variables on workfamily conflict and strain: A control perspective. Journal of Applied Psychology, 80, 6-15.

Valcour, M. 2007. Work-based resources as moderators of the relationship between work hours and satisfaction with work-family balance. Journal of Applied Psychology, 92(6), 1512-1523.

Voydanoff, P. 2004. The effects of work demands and resources on work-to-family conflict and facilitation. Journal of Marriage and Family, 66(2), 398-412.

Voydanoff, P. 2005a. Wok demands and work- to- family and family-to-work conflict: direct and indirect relationships. Journal of Family Issues, 26, 707-726.

Voydanoff, P. 2005b. Toward a conceptualization of perceived work-family fit and balance: a demands and resources approach. Journal of Marriage and Family, 67, 822-836. 
Waye, J.H., Musisca, N., Fleeson, W. 2004. Considering the role of personality in the workfamily experience: Relationships of the big five to work- family conflict and facilitation. Journal of Vocational Behavior, 64(1), 108-130.

Wallace, J.E. 1997. It's about time: a study of hours worked and work spillover among law firm lawyers. Journal of Vocational Behavior, 50, 227-248.

White, J.M. 1999. Work-family stage and satisfaction with work-family balance. Journal of Comparative Family Studies, 30(2), 163-175. 